\title{
MAKING A SANCTUARY CITY: AN EXPLORATORY STUDY OF POLICE SERVICE POLICIES AND PRACTICES TOWARDS UNDOCUMENTED/NON-STATUS COMMUNITY MEMBERS IN ONTARIO
}

\author{
by
}

Mia Sara Hershkowitz, BA, Humber College, 2016

\author{
A Major Research Paper \\ presented to Ryerson University \\ in partial fulfillment of the requirements for the degree of \\ Master of Arts \\ in the program of \\ Immigration and Settlement Studies
}

Toronto, Ontario, Canada, 2018

(C) Mia Sara Hershkowitz 2018 


\section{AUTHOR'S DECLARATION}

AUTHOR'S DECLARATION FOR ELECTRONIC SUBMISSION OF A MAJOR RESEARCH PAPER (MRP)

I hereby declare that I am the sole author of this Major Research Paper. This is a true copy of the MRP, including any required final revisions.

I authorize Ryerson University to lend this MRP to other institutions or individuals for the purpose of scholarly research

I further authorize Ryerson University to reproduce this MRP by photocopying or by other means, in total or in part, at the request of other institutions or individuals for the purpose of scholarly research.

I understand that my MRP may be made electronically available to the public.

Mia Sara Hershkowitz 


\title{
MAKING A SANCTUARY CITY: AN EXPLORATORY STUDY OF POLICE SERVICE POLICIES AND PRACTICES TOWARDS UNDOCUMENTED/NON-STATUS COMMUNITY MEMBERS IN ONTARIO
}

\author{
Mia Sara Hershkowitz \\ Master of Arts 2018 \\ Immigration and Settlement Studies \\ Ryerson University
}

\begin{abstract}
This paper explores the policies and practices of police services in Ontario as they relate to undocumented/non-status community members. The study findings, via interviews with senior police officers, are discussed regarding implications on service provision and police service development of sanctuary city policy and/or the adherence to municipalities' designation as a sanctuary city. The Toronto Police Service is the only police service in Ontario that has a formal directive on service provision towards undocumented/non-status persons. The current procedure is that once it becomes known to a police officer that someone is undocumented the Canada Border Service Agency is contacted and the municipal police service is no longer involved. The challenges in shifting current police practices are identified.
\end{abstract}

Key words: sanctuary cities; municipal police services; Don’t Ask Don’t Tell; immigration status; formal/informal police service policy 


\section{ACKNOWLEDGEMENTS}

To my supervisor Dr. Graham Hudson, it is with my deepest gratitude I thank you for your guidance, patience, insight, and compassion that you provided me with in the realization of this paper. Thank you for your help in overcoming all the barriers and for your commitment to seeing this work through the process of creating something I can be proud of.

To my second reader Dr. Harald Bauder, thank you for your expertise and the time you committed and for your recommendations, which challenged me to deepen my knowledge of this subject area.

Thank you to Igor Rosic, Immigration and Settlement Studies Graduate Program Administrator, for your kindness and for keeping me on track to see this through to its completion. 


\section{DEDICATION}

To Joe Couto, for being the embodiment of unwavering mentorship and support.

To Dayana Gonzalez Mateus and Saad El Hakmi whose wisdom and encouragement is boundless.

To my parents, Daniel, Amy, and Elaine, for all they have done.

To Zion and Dov, it has all been for you. 


\section{TABLE OF CONTENTS}

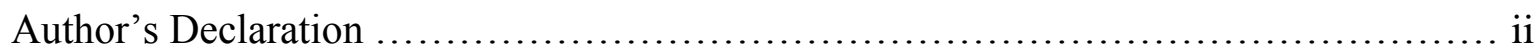

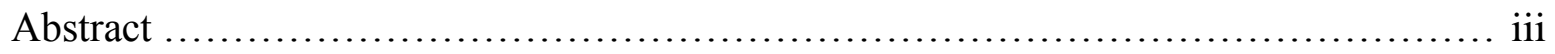

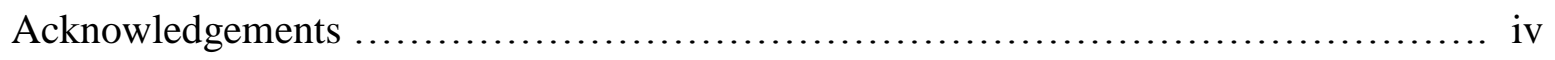

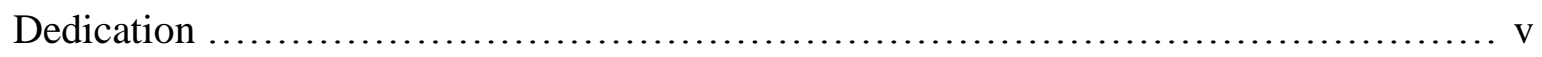

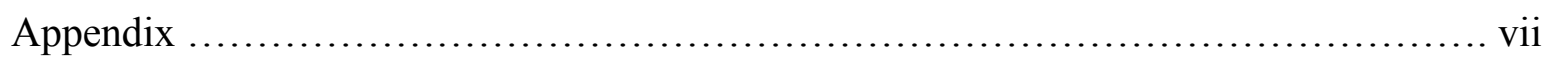

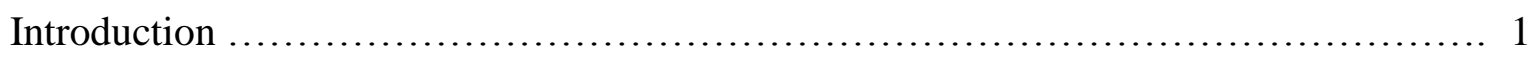

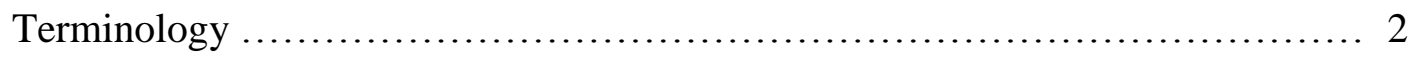

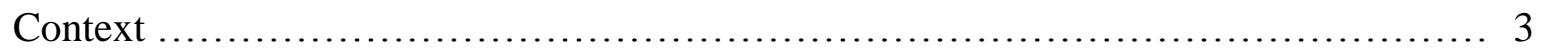

Police Service Policies Surrounding Undocumented/Non-Status Individuals ..... 3

Municipal Policies Surrounding Undocumented/Non-Status Individuals .......... 6

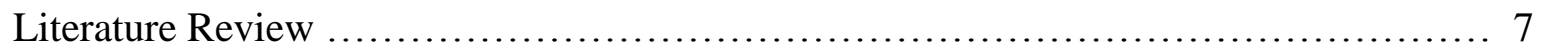

Defining and Redefining Citizenship ................................. 7

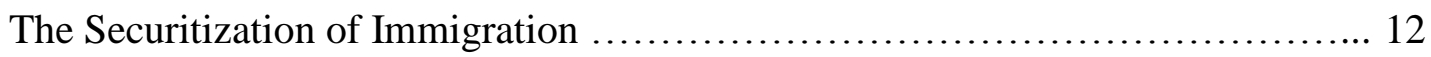

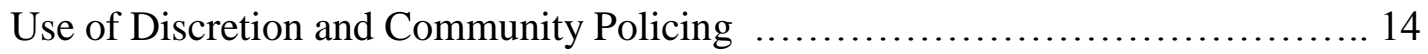

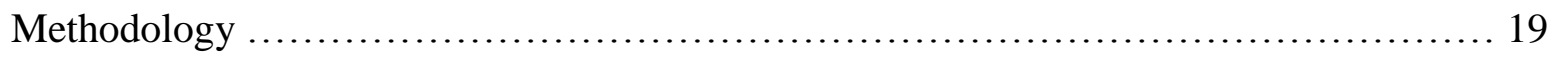

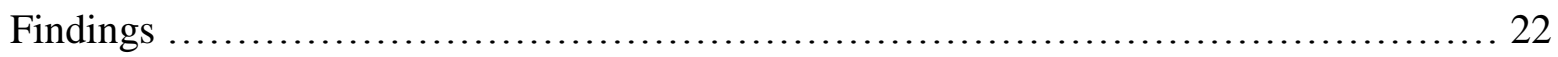

Police Service Policies and Practices ................................... 22

Challenges Creating Sanctuary City Policy in the Context of Policing .............25

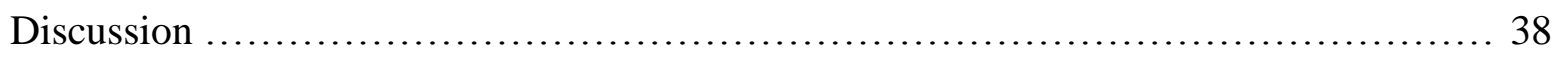

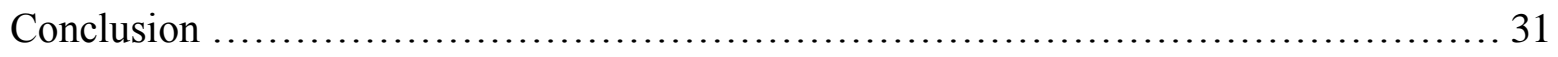

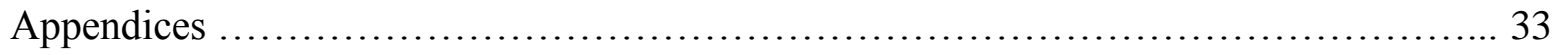

Reference List ........................................................... 36 


\section{LIST of APPENDICICES}

Appendix A: Toronto Police Service Board Draft............................... 33

Appendix B: Victims and Witnesses Without Legal Status.......................................... 34

Appendix C: Interview Guide................................................. 35 


\section{INTRODUCTION}

While it is difficult to determine how many undocumented/non-status individuals live in Ontario, it is estimated there are as many as 500,000 (Goldring, Berinstein and Bernhard, 2009). Community organizations, advocates, and academics have been highly involved in exploring the challenges the non-status population experiences, including lack of access to basic public services and rights. The so-called "sanctuary city movement" is gaining momentum in Canada (Bauder, 2017). The action of municipalities to enact sanctuary city policy demonstrates some level of political will to recognize the presence of this population in our cities. At a minimum, sanctuary city policy aims to provide municipal and police services to all residents, regardless of immigration status. Since a key barrier to access is fear of detection, the role of police services is of paramount concern.

It is difficult to determine exactly how many undocumented people live in Canada because there are no official statistics (City of Toronto, Social Development, Finance \& Administration, 2012). But literature identifies that undocumented/non-status individuals are not only living in Toronto, but also experiencing significant challenges accessing municipal services based on their immigration status (Magalhaes, Carrasco and Gastaldo, 2010). Hudson, Atak, Manocchi and Hannan (2017) identify that for undocumented individuals "a particularly serious problem is lack of access to the police services" (p. 6). While literature identifies the challenges people without status have in accessing police services (Nayers, 2010; Bauder, 2016), there is limited literature available from the perspective of police services or police officers.

Ontario's Provincial policing strategy, Ontario's Mobilization \& Engagement Model of

Community Policing, is a community-policing model, which is centered on police-community partnership (Whitelaw and Parent, 2010). The Ontario Association of Chiefs of Police (2010) 
define community policing as, "the process by which police and other community members partner to improve community wellbeing, safety and security through joint problem identification, analysis, response and evaluation" (para. 4). According to Armenta and Alvarez (2016), "although law enforcement agencies are overwhelmingly supportive of the idea of community policing, they are largely resistant to changing enforcement tactics that criminalize immigrant communities" (p. e12458). There is tension between the undocumented/non-status community and police services when police officers enforce immigration law, which additionally undermines the police-community partnership (Deshman, 2009). Therefore, the purpose of this Major Research Paper is to identify, via interviews with police officers, the policies and practices of municipal police services in Ontario as they relate to undocumented/non-status individuals.

I have employed the following method: 1) Interviews with police officers, through which I identify both formal and informal polices and practices of the procedural guidelines for interaction between police officers and undocumented/non-status individuals, 2) A comparative analysis of themes gathered from the interviews across different police services in Ontario, 3) A comparison between the policies and practices of police services within municipalities that have sanctuary city policies, and police services in municipalities that do not have sanctuary city policies, and 4) Analysis of provincial and municipal legislation that both enable and hinder sanctuary city policy. Identifying police service policies and practices provides an opportunity to increase transparency and trust in police services, and contributes to public dialogue on police accountability, and community partnership.

\section{Terminology}

There is no settled definition of the population of persons who lack (secure) immigration status. For the purpose of this study the following terminology will be used: Undocumented/non- 
status community members (Goldring et al., 2009), which refers to a person who does not have formal legal status or citizenship. This includes one who has entered and/or remains in Canada without authorization by the feral government. In particular, it includes people who entered the country without permission and have not since acquired it, entered with permission but have had their status revoked, over stayed their visa, or have not complied with a removal order.

The term "formal policies" will be defined as rules, procedures, standards, and directives produced by City Council or any other authority empowered to do so through enabling provincial statutes or regulations. "Informal policies" include consistent practices and customs that are not codified, but that together achieve an institutional principle and/or goal. "Sanctuary city" refers to a policy where the city provides municipal and police services to all residents, regardless of immigration status. The policy further directs that municipal officials 1) do not collect immigration/ citizenship information for the purpose of determining service eligibility and 2) do not share personal information with federal authorities, unless specifically required to do so by provincial or federal legislation (City of Toronto, 2014).

\section{CONTEXT}

\section{Police Service Policies Surrounding Undocumented/Non-Status Individuals}

In November 2004 a complaint was filed with the Toronto Police Service, alleging that the Toronto Police Service "has a practice of inquiring about the immigration status of persons seeking police services and of providing that information to immigration authorities" (Toronto Police Services Board, 2005, p. 6). The complainant stated further that, "this practice of asking for and reporting immigration status where people are seeking the protection of the police hinders public safety. If a person fears contacting the police for fear of deportation even when he 
or she may be the victim of or the witness to a serious crime, people who should be prosecuted for serious criminal offences will remain at large and remain a threat to the community" (Toronto Police Service Board, 2005, p. 6). The Toronto Police Service, Corporate Planning Division conducted a review and concluded that there was no requirement to change the procedures or policies of the Toronto Police Service (Toronto Police Services Board, 2005).

The complainant appealed the decision that no further action was required on the part of the Toronto Police Service, initiating a review of the complaint by the Toronto Police Services Board and subsequent draft of Ontario's first ‘Don't Ask Don't Tell' (DADT) policy (Toronto Police Services Board, 2005). Deshman (2009) explains that DADT policy has two separate components, 'Don't Ask', which prevents police officers from inquiring into victims' or witnesses' immigration status and 'Don't Tell', which would mandate that the police treat personal information as confidential, restricting the ability to communicate this information to federal immigration and border services agencies. The Toronto Police services Board (2006) recommended the approval of a "Non-status Victim and Witness Policy" (p. 18) (See Appendix A).

In March 2007 Chief Blair responded to the request of the Toronto Police Service Board with the directive Victims and Witnesses without Legal Status - which excluded the 'Don't Tell' component (Toronto Police Services Board, 2008) (See Appendix B). Chief Blair justified the exclusion of the 'Don't Tell' component on the premise that it would require Toronto Police Service officers to contravene their statutory duty as legislated by the Police Service Act (PSA) (Deshman, 2009). Chief Blair cited the Oath of Office all police officers in Ontario are required to take in support of this position: "I solemnly swear (affirm) that I will be loyal to Her Majesty the Queen and to Canada, and that I will uphold the Constitution of Canada and that I will, to the 
best of my ability, preserve the peace, prevent offences and discharge my other duties as (insert name of Office) faithfully, impartially and according to law" (O. Reg. 144/91, PSA); and Section 42(1) of the PSA that states the duties of a police officer including: a) preserving the peace; and b) preventing crimes and other offences and providing assistance and encouragement to other persons in their prevention (Toronto Police Services Board, 2005).

The main point of concern from the perspective of the Toronto Police Service was whether officers could use their discretion once they are in possession of knowledge, however it was obtained (i.e. reporting a crime) about an individual's immigration status (Toronto Police Services Board, 2008). A 'Don't Tell' policy would ensure that if a Toronto Police Service officer became aware of immigration status, in the case where a person does not have status, the officer would not contact federal immigration officials. The argument presented by the Chief was that the PSA mandates the prevention of crime and other offences, and since not having citizenship and residing in Toronto is "illegal" it must be reported to the Canadian Boarder Service Agency (CBSA).

In response to Chief Blair's concerns The Toronto Police Service Board put together a working group to try and determine the feasibility of implementing the 'Don't Tell' portion; the biggest concern was determining if "there is a duty under Ontario law for police to disclose immigration status to the CBSA" (Toronto Police Services Board, 2008, p. 54). While the working group presented a report which concluded that implementing a 'Don't Tell' policy would not require officers to contravene their oath under the PSA, Chief Blair maintained their was still no definitive clarity on the issues of legality and liability and therefore would be excluded (Toronto Police Service Board, 2008). This decisions has been criticized that the exclusion of the 'Don't Tell' component decreases the effectiveness of the policy and does not 
provide adequate protection for undocumented/non-status community members (Deshman, 2009).

\section{Municipal Policies Surrounding Undocumented/Non-Status Individuals}

In February 2013, Toronto City Council voted to become a "sanctuary city", the first city in Canada to do so (Hudson et al., 2017). The term "sanctuary city" does not refer to one specific policy; it includes a range of different policies and practices (Bauder, 2016). The objective is to improve access to essential services such as health care, access to police services and primary school education, which are otherwise denied to undocumented/non-status individuals (Ellis, 2015). The development of Toronto's sanctuary city policy was initiated in October 2012, with a City of Toronto report by the Executive Director of Social Development, Finance \& Administration, entitled Undocumented Workers in Toronto (City of Toronto, Social Development, Finance \& Administration, 2012). On February 20, 2013 Toronto City Council made the following decision, "City Council re-affirm its commitment to ensuring access to services without fear to immigrants without full status of without full status documents" (City of Toronto, City Council, 2013, para. 1). In 2014, the initiative was formally named Access T.O., and according to Hudson et al. (2017) the primary objective is "to ensure that all residents are able to access municipal and police services, regardless of immigration status" (p. 2).

It is important to differentiate between Access T.O. and the Toronto Police Service directive Victims and Witnesses Without Legal Status (Don't Ask). Access T.O falls under the municipal jurisdiction of the City of Toronto and is a separate policy from the Toronto Police Service policy 'Don't Ask'. The PSA legislates who can make decisions regarding police service operations in Ontario. According to the PSA municipalities do not have the jurisdictional power 
to make decisions regarding police service practices (although there are contentions about whether this is truly the case), therefore the Toronto Police Service is not bound or formally accountable to adhere to Access T.O. Toronto City Council had made attempts to leverage the Toronto Police Service to adhere to the principles of Access T.O., including a decision in 2015 requesting that the Toronto Police Service Board respond and report back to city council on the following issues: 1) statistics on the number of undocumented/non-status community members reported by the Toronto Police Service to the CBSA, 2) agreements that exists between the Toronto Police Service and the CBSA, 4) practical implementation of the Access without Fear policy, and 5) and the possibility of amending the PSA to regulate that police officers only report immigration status to the CBSA when directed by the courts after a conviction has been registered (City of Toronto, City Council, 2015). The Toronto Police Service has yet to respond. This is reflective of the on-going tension between municipalities and police services regarding sanctuary city policy. City Council decisions to become a sanctuary city do not have any legal impact on police services and their service provision towards undocumented/non-status community members. Police services are governed by provincial legislation therefore municipalities have no jurisdictional authority on the operations of police services. The tension is between municipal and provincial jurisdictional authority.

\section{LITERATURE REVIEW}

\section{Defining and Redefining Citizenship}

A traditional understanding of citizenship is to view citizenship rights, responsibilities, and membership, as confined to the nation state (Purcell, 2003). From this perspective citizenship is defined as a 'legal status', which confers certain protections and rights within the 
nation-state (Staeheli, 2003). Most fundamental to the traditional definition of citizenship is the ability to participate in governance, the 'right' to vote (Staeheli, 2003). Citizenship is the denotation of "full membership in society" (Holston and Appadurai, 1996). Contemporary debates surrounding the concept of citizenship demonstrate how societies are challenging the meaning of citizenship beyond its rigid legal category (Staeheli, 2003). Emerging from this debate is a distinction between formal and informal citizenship. Informal citizenship reflects the variety of ways citizenship is being reconceptualised as a unique category of its own, separate from the categorization of formal citizenship as a legal status that is acquired through federal recognition. Emerging meanings of informal citizenship include characteristics such as political participation and social relationships.

To reflect the changes to contemporary understanding of citizenship that includes both formal and emerging meanings of informal citizenship, Purcell (2003) offers a broad definition of citizenship as, "rights and responsibilities that are associated with membership in a political community" (p. 566), whereas 'political community' is defined widely to reflect varying groups that organize based on a shared political interest. Purcell (2003) suggests that there are three principal characteristics that are reflective of emerging alternative forms of citizenship: "citizenship is being rescaled (the former hegemony of the nation-scale political community is being weakened by the creation of communities at other scales); reterritorialized (the link between the nation-state's territorial sovereignty and political loyalty have been increasingly open to question); and reoriented (the nation is no longer the predominant political community)" (p. 566, emphasis in original). Another emerging conception of citizenship is "social citizenship" which is based on social relationships (Isin, Brodie, Juteau and Stasiulis, 2008). According to Isin et al. (2008), "a focus on the social in citizenship challenges the notion that citizenship 
comprises static and universalistic legal status of abstract individuals in nation-states" (p.11).

From this perspective engaging in social struggle (i.e. the struggle for recognition) is an enactment of citizenship (Isin et al., 2008).

Global migration trends are an important contextual factor in the debate about citizenship. Some scholars have argued that as a result of globalization, social practices are being extended and reproduced between countries of origin and new localities. This process is referred to as transnationalism. An often cited definition of transnationalism is conceptualized by Basch, Glick Schiller and Szanton Blanc (2003) as "the process by which immigrants forge and sustain multistranded social relations that link together their societies of origin and settlement... building social fields that cross geographical, cultural, and political border" (p. 8). A point of contention in transnational scholarship surrounds the concept of de-territorialization, explained as a weakening of national borders resulting from transnational practices (Basch et al., 2003). It has been argued that this concept does not consider the full force of the nation-state (Pries, 2009) that while de-territorialization is accomplished partially through transnational practices, as a result of nation-state action, "there is a simultaneous and equally forceful process of re-territorialisation" (Jackson, Crang and Dwyer, 2004, p. 6). Examples of re-territorialisation include stricter requirements for citizenship, "such as the spread of citizenship tests and innovations in legal (and extralegal) ways of revoking citizenship" (Nyer and Rygiel, 2012, p. 1). While restrictions to mobility and citizenship are responsible for generating multiple forms of exclusion, according to Nyer and Rygiel (2012), "the practice and experience of mobility - even when restricted - is itself productive of new forms of citizenship and of being political” (p. 1).

The definition and classification of "non-status" is complex. Status is often not static and fluctuates between different degrees of legality, for example, the denial of a refugee claim or the 
expiration of a work permit (Nyers, 2010). A crucial perspective to any critical exploration of citizenship must be grounded in the recognition that the classification of "non-status" is a political construct (Nyers, 2010). The denial of formal citizenship is not only the denial of rights, but also the denial of non-status persons as political agents (Nyers, 2010). To be a non-status person is to be spoken for, about, or silenced (Nyers, 2010). The sanctuary city movement in Canada challenges this denial of political agency. Social justice movements that present different conceptions of citizenship are described as enacting citizenship "from below" (Nyer and Rygiel, 2012, p. 7). For example, “sanctuary movements, No Border politics and Don’t Ask Don’t Tell campaigns put forward different normative visions of the future, in which notions of belonging and entitlement to rights are founded on criteria of residence, participation in community, and social relations (Nyer and Rygiel, 2012, p. 9).

\section{The City}

Scholarship is challenging the traditional notion of citizenship advocating for new criteria and characteristics that comprise informal forms of citizenship. Within this on-going debate has begun the recognition of the central role of the city in the construct of citizenship, both formal and informal (Staeheli, 2003). According to Staeheli (2003) the significance of the city is based on the premise that citizenship is a process, rather than a status, whereas, "processes of inclusion and belonging are at the core citizenship" (p. 99). This conception of citizenship extends the definition beyond the nation-state into the community and spaces where social belonging is constructed. Therefore, according to Staeheli (2003), "the struggles and practices of citizenship are powerfully shaped and conditioned by spatial relationships and the geography of the city" ( $p$. 99). 
Social activism is a key process in challenging the restrictive definition of formal citizenship and as a site that enables its reconception (Nyer and Rygiel, 2012). When social movements challenge the social conditions and inequity of urban poverty there is the demand for new forms of rights, such as housing, education, health care, this struggle not only affirms access to these rights, but creates a new meaning of citizenship; as Holston and Appadurai (1996) explain, "as the social movements of the urban poor create unprecedented claims on and to the city, they expand citizenship to new social bases. In so doing, they create new sources of citizenship rights" (p. 198). The city then provides the context for resistance of which, through struggle, citizenship can be reimagined (Holston and Appadurai, 1996). Further, according to Isin (2008), "even in its modern form, where belonging to the city does not confer any formal rights or status to the citizen (as belonging to the state does), belonging to the city confers substantive rights by virtue of being a space with a special government and legal jurisdiction" ( $p$. 271). The sanctuary city movement is demonstrative of this process, where the city enables resistances to and challenges the criminalization of those the nation-state has deemed ineligible to receive formal citizenship (Ridgley, 2008). Sanctuary city campaigns provide a platform where non-status people are enacting claims to political identity (Nyers, 2010). According to Nyers (2010) the mobilization of ones 'voice' is a political act and constitutes the enactment of informal citizenship. For example, to self-identify as "non-status" is the declaration of a political identity and political subjectivity, and thus understood as an act of citizenship (Nyers, 2010). Isin (2008) explains, "social struggles enable people to enact themselves as citizens as well as engage in questions of justice" (p. 275). 


\section{The Securitization of Immigration}

According to Bauder (2008) "danger and fear of immigration are not ad hoc responses to September 11 but rather more consistently and systematically engrained in Canadian immigration discourse" (p. 306). While the process of conflating immigration with threat to national borders precedes $9 / 11$, it provided justification to enhance and develop new practices of border control. According to Rygiel (2008) as subsequent response to 9/11 was "countries seizing the moment to implement new border control and detention arrangements" (p. 210). Securitization theory provides a framework to understand the securitization of immigration and the subsequent involvement of municipal police services' in the enforcement of immigration law (Rygiel, 2008). From this perspective security is defined as an existential threat that justifies the use of extraordinary measures by the state (Watson, 2012).

The securitization of the immigrant 'other' has provided the justification for the enhanced role of municipal police services in immigration control and the localization of border control (Ridgley, 2008). As a result, "non-status migrants live in constant fear of detention, deportation, and surveillance by the authorities" (Nyers, 2010, p. 132). According to egas (2015), “deportability involves the process of disciplining illegalized migrants through deportation, the threat of deportation, and/or the constant feeling that one could be deported at any point in time" (p. 234, emphasis in original). Buzan \& Wæver (2003) define securitization as, "the discursive process through which an intersubjective understanding is constructed within a political community to treat something as an existential threat to a valued referent object, and to enable a call for urgent and exceptional measures to deal with the threat" (p. 491). According to Balzacq \& Guzzini (2015), the central consequence of securitization is that it gives policy makers the ability to adopt immediately "whatever means they deem appropriate to curb the threat" (p. 99). 


\section{Consequences of Securitization}

Buzan, Wæver, de Wilde (1998) explain the consequences of security status, "the invocation of security has been the key to legitimizing the use of force, and a way for the state to mobilize, to handle existential threats" (p. 21). Buzan \& Wæver (2003) explain further that it results in "investigation and prosecution beyond constitutional and legal normality" (p. 297). For securitization to occur, "elite discourse must conflate immigration with terrorism and deliberately exploit the public's fear of immigration" (p. 552). According to Messina (2014), "September 11 is viewed as a critical juncture in and a major accelerant of the process of securitizing immigration in Europe and the United States (p. 533). According to Burman (2010), "global migration has been increasingly criminalized and immigration policy made more closely linked to national security" (p. 203). According to Muller (2004) since the events of 9/11 and the subsequent 'war of terror', "there has been a dramatic, and often draconian, securitization of the politics of borders and bodies" (p. 281). According to Lennox (2007), "typical democratic checks and balances, bureaucratic safeguards and budgetary processes need not apply once an issue has been securitized" (p. 1021). Anti-immigrant policies are grounded in a message that the assumed values of the "other" are not welcome (Gaucher, 2016). Immigration enforcement is exclusively a federal jurisdiction. However, Coleman and Kocher (2011) argue that as a result of securitization practices that took place post 9/11, immigration policing has been expanded to non-federal law enforcement agencies. The result is that immigration enforcement now takes place in "non-border spaces" (Coleman and Kocher, 2011, p. 228). The localization of immigration enforcement causes non-status community members to, "experience multiple borders and sites of surveillance and discipline in their day-to-day lives" (Villegas, 2015, p. 251). 


\section{Use of Discretion and Community Policing}

The decision to inquire about immigration status is reliant on police officers' use of their discretion. To look 'illegal' from the perspective of police officers may be the motivation for traffic enforcement, citations, or arrest (Sweeney, 2014), and subsequently ones status becoming known. In the case of undocumented/non-status community members once status is known to the police they are vulnerable to be reported to federal immigration officials. Therefore the context of decision making in regards to use of discretion is important. The main themes that arise regarding discretion and the policing of undocumented/ non-status community members include: exploring how police officers construct and subsequently profile who look "illegal", and the conflation between immigration status and 'security threat'.

In the context of policing, the use of discretion is defined as "the decision not to invoke formal social control even when the circumstances warrant or legally allow for it" (Schulenberg, 2012, p. 299). As Wortley (2003) explains, "police have the ability to act as more or less autonomous agents" (p. 538), thus they can simply choose not to ask immigration status. There are also possible negative consequences, as Wortley (2003) explains, "selective enforcement of the law allows police to redefine justice in terms of their own priorities, which might not correspond to the priorities of the wider community" (p. 539). This may be reflected in police officer resistance to upholding sanctuary city policy. Municipal police officer authority and discretional powers are granted under the Police Services Act (PSA).

Police services argue that they have a duty to report immigration status to federal authorities (Toronto Police Services Board, 2005). This is reflective of the tension that arises regarding police services implementation of 'Don't Tell' policy. While police services have justified the exclusion of a 'Don't Tell' policy based on the argument it would be contravening 
their sworn oath of office, legal scholars have countered that without this policy in place nonstatus/undocumented community members cannot safety access police services (The Immigration Legal Committee, 2008). They also insist that, legally speaking, "police have no duty to report immigration status" (The Immigration Legal Committee, 2008, p. 2).

The context of policing in Ontario is important, because Ontario's provincial policing strategy, Ontario's Mobilization \& Engagement Model of Community Policing, is a community based policing model. Principles of community policing such as, partnership, engagement, and trust have become essential elements of evaluating service provision (Whitelaw and Parent, 2010). Police Services in different municipalities in Ontario have implemented programs to encourage community partnership. For example, in May 2013 The Toronto Police Service implemented the Neighbourhood Policing Program. The program was created as a response to the strained relationship between community members and police officers in Toronto. The present relationship between police and community represents both a complexity of challenges and also a unique opportunity to address social constructs of inequity (Meng, 2017), including “illegalized” migration status (Bauder, 2014).

The following will explore police officer use of discretion in providing service to undocumented/non-status community members. Incorporating the influence of factors such as race, nationality, religion, culture, and gender (Pratt and Thompson, 2008). Further, it will be explored how new realms of informal citizenship (i.e. social citizenship) are enacted through social movements. According to Isin et al. (2008), "citizenship involves the art of being with others, negotiating different situations and identities and articulating ourselves as distinct yet similar to others in our everyday lives, and asking questions of justice. Through these social struggles, we develop our sense of our rights as others' obligations and others' rights as our 
obligations" (p. 7). The sanctuary city movement can be understood as facilitating informal citizenship through building relationships that foster belonging. The struggle for the rights of undocumented/non-status community members ties society to a shared responsibility of transforming inequality. As Bauder (2017) states, "the process of identity formation lies at the heart of societal transformation" (p. 109). Identity formation is applied to understanding the use of discretion in the case of inquiry into immigration status, contextualizing factor such as race, ethnicity and other socially constructed categories of "other", and to new constructs of informal citizenship that are premised on political participation and social relations.

\section{Identity Formation}

In Phenomenology of Spirit, originally published in 1807, Hegel (1977) writes, "Selfconsciousness exists in itself and for itself, in that, and by the fact that it exists for another selfconsciousness; that is to say, it is only by being acknowledged" or "recognized" (Line 178, p. 318). Hegel explains that individual self-consciousness exists only when another recognizes it. Central to Hegel's conception of the process of recognition is reciprocity. The mediation of the self through the other comes at the moment when the two self-conciousnesses come together. A struggle takes place when each consciousness seeks to incorporate the other within its field of consciousness or differentiate the self from the other. For this process to take place, to recognize another, one must be recognized as a subject capable of giving recognition. Hegel's (1977) master and slave dialect demonstrates the requirement of mutual reciprocity between "equals" in the process of recognition. In Black Skin White Mask, the Hegelian master and slave dialectic represents an important contention for Fanon (1967), who states, "there is of course the moment of "being for others," of which Hegel speaks, but every ontology is made unattainable in a colonized and civilized society" (p. 82). According to Hegel, consciousness comes into existence 
through the mutual struggle for recognition; Fanon contends the impossibility of this concept in the colonial context. Where Hegel conceptualizes identity formation as a process of mediation through the other, Fanon explains it not as a reciprocal process, rather a violent imposition of identity. The process of recognition for Fanon is symbolic of the power structure that governs the relationship of reciprocity.

Schulenberg (2012) explains that police culture is often attributed to use of discretion because "police culture creates pre-constituted typifications and stocks of knowledge that lead officers to prejudge what they encounter in the field" (p. 299). According to The Immigration Legal Committee (2008), “questions about status are used by police to justify stops made primarily on the basis of race" (p. 2). This is reflective of the relationship between factors such as race, nationality, religion, culture, and gender and police practices towards undocumented/ non-status community members. The Immigration Legal Committee (2008) state immigration status has become a tool for racial profiling. The use of discretion is influenced by the perception of who looks "illegal". While the construct of who looks "illegal" is based on racialized markers, arguments against racial profiling are muted by the justification that policing practices are race neutral (Aleinikoff, 1991). However, Provine and Doty (2011) state that, "the combination of increased surveillance and sanctions, agency hype, and everyday practice together produce an immigrant "other" whose continued presence is increasingly perceived to be dangerous for the security and integrity of the nation" (p. 264).

In response to $9 / 11$ border control and detention activities were enhanced, targeting specifically undocumented/non-status community members (Cole, 2012). Rygiel (2008) explains, "securitization processes construct and then marginalize certain groups as threatening and undesirable" (p. 212). Undocumented/non-status community members are constructed as a 
'security threat'. Subsequently, action can be taken to remove this theat. As Rygiel (2008) states, "detention practices, in effect, remove from society those groups of non-citizens or abject subjects thought to be undesirable or as not belonging properly within a state" (p. 216). This is reflective of Fanon's (1967) critique of identity formation - that identity is not formed reciprocally. Rather, in case of the colonizer and the colonized or police officer and undocumented/non-status community member, identity is imposed by the one who has power over the other. The construct of who is a 'security threat' reveals the influence of power in the relationship of reciprocity and identity formation (Fanon, 1967). Police have the power to distinguish who is the "other" (i.e. 'security threat'). Undocumented/non-status community members have the identity of "illegal" and 'security threat' imposed upon them. If police officers view undocumented/non-status community members as a 'security threat' this judgment may influence their use of discretion.

The securitization of citizenship is a dual process. In constructing a certain group as threatening and the 'other', it also raises challenges to the traditional form of rigid formal citizenship, as the marginalized group respond with social movements that claim belonging in the society (Rygiel, 2008). As Rygiel (2008) explains, "The No One Is Illegal and No Border movements, for example, are challenging the very groups that underpin modern citizenship, based on nations of a securitized and legalized subject, on which to legitimize the awarding and withholding of rights and resources. In the process, these movements present alternative visions of what the social in citizenship might entail” (p. 212). It is these forms of activism that creates solidarity between members of society and through a shared struggle creates a collective responsibility for equality in rights including citizenship. As Bauder (2017) explains, "from a Hegelian perspective, identity always requires the reference point of the other" (p. 111). 
Therefore these social movements can be viewed as contributing to an individual and collective social identity that solidifies the belonging of undocumented/non-status community members as citizens with full access to the rights which that entails. As Bauder (2017) states, "it bonds people who are in different social and political circumstances, such as citizens and illegalized migrants" (p. 111).

\section{METHODOLOGY}

\section{Research Design}

The study employed a mixed methodology including interviews with police officers and documentary analysis. The central component is qualitative interviews, which allowed for an exploration of both formal and informal police service policies and practices surrounding undocumented/non-status community members and for a comparative analysis of themes across different police services in Ontario including a comparison between the policies and practices of police services within municipalities that have sanctuary city policies, and police services in municipalities that do not have sanctuary city policies. A documentary analysis of provincial and municipal legislation contextualizes the interview findings, distinguishing the authoritative powers regarding sanctuary city designation, policy development, and implementation as between police services and municipalities in Ontario._This methodology is chosen because according to Neuman and Robson (2012) qualitative research has the ability to, "capture an inside view and provide a detailed account of how those being studied feel about and understand events" (p. 113). The primary data source is semi-structured interviews. Purposive sampling was used to recruit participants (Guba and Lincoln, 1988). The inclusion criteria is: 
- Police officers who have a high rank within their police service, including, Chief, Superintendent, Staff Inspector, Inspector, or Staff Sergeant.

- Employed with police services from different municipalities in Ontario, including Peel Regional Police Service, Toronto Police Service, London Police Service, Waterloo Police Service, Cornwall Police Service, Halton Regional Police Service, and Ottawa Police Service, etc..

The Toronto Police Service was chosen specifically because the city of Toronto is a sanctuary city and provides a good point of comparison to police services within municipalities that are not sanctuary cities. High-ranking police officers are the target of this research because of structure of decision-making authority and the nature of which information is disseminated through police services. Police services are organized within a hierarchal structure. Police service policies and directives are developed and disseminated from a top down approach.

\section{Participant Recruitment}

The study required multiple levels of approval before participant recruitment was initiated. Ryerson University Research and Ethics Board (REB) approved the study. To obtain REB approval the study first had to be approved by the Ontario Association of Chiefs of Police (OACP). The OACP provided a letter of permission to conduct this study including approval of the study methodology. Initial recruitment began with contacting the Chief of the police services included in the study criteria. The study had to be first approved by each individual police service Chief. An email template explaining the purpose of the study, participant inclusion criteria, and the consent documentation was sent to 13 municipal police services in Ontario. Of the 13 Chiefs contacted, 8 provided permission for their police services to take part in the study. Once this approval was received, the participant request was passed down the chain of command 
to determine who within the individual police services would be an appropriate participant. Contact information was provided for potential participants from each police service. The final step of recruitment included contacting these potential participants through email and phone. Once initial contact was made with a police officer, it was explained that participation was voluntary and they were emailed the consent agreement to review. A total of 8 police services participated in the study (Cornwall Police Service, Peel Regional Police Service, Halton Regional Police Service, Toronto Police Service, Ottawa Police Service, Windsor Police Service, London Police Service, and Waterloo Police Service). The study sample includes a total of 11 participants. The interviews were semi-structured and were an average of an hour in length. (See Appendix $\mathrm{C}$ for interview guide). Interviews were recorded with the consent of the participants.

\section{Data Collection and Analysis}

Subject to consent, some personal information was collected, including name and place of employment. E-mail addresses were collected so that a written transcript of the interview can be returned to participants for review. Participants were given their transcript for review as a method of ensuring the validity of the study (Polkinghorne, 2007).

\section{Potential Risks}

The risks associated with participation were low. To reduce risk participants were informed that they are not required to answer questions they are uncomfortable with, and the interview can be stopped at any time, either temporarily or permanently.

\section{Confidentiality}

There is a low risk that identity could be revealed, to reduce this risk interviews were conducted with the use of pseudonyms. Data was stored separately, in different password 
protected files, from identifying information. The audio recordings of the interviews were destroyed once transcribed.

\section{FINDINGS}

\section{Police Service Policies and Practices}

The Toronto Police Service is the only police service in Ontario that has a formal directive on police operations towards undocumented/non-status persons. Further, there is an unresolved debate and contention to whether the Police Services Act (PSA) legislates that police offices have a responsibility to report immigration status to federal authorities. As such, it is of interest to explore whether in the void of formal policy if police services have informal policies that influence policing practices towards undocumented/non-status community members. There was a unanimous response from participants, in regards to this question that, there is no such thing as informal policies. As one participant stated:

Just to be clear about your question about informal procedures, we have no informal procedures, we have the formal ones for all the reasons that we clearly outlined and we follow them. There is no 'in addition to the formal ones, we have secondary informal ones that we do', we have none of those (Participant 1, Inspector).

Another participant shared a similar sentiment, that within policing informal policies do not exist. They further offered an alternative concept to informal polices, which from their perspective was more applicable to the policing context, culture and attitude. As they explained:

When you are talking informal policies, I don't think there is any such thing as informal policies, you may have culture and attitude. Culture and attitude, which as you've referred to, the informal polices, and it's a very real area that we have to be concerned about, because how you build culture, then depends how the conduct is from our officers. You know, I have been in [municipality] for 14 years now, and I can honestly say, I don't see an attitude, a predominant attitude, in the front line or even support staff or anyone else dealing with, immigration issues (Participant 2, Chief of Police). 
Another Inspector also shared a similar perspective on attitude when discussing informal policies, but focused on the individual aspect, excluding culture:

No, there is no unofficial or subversive, policies we don't have anything like that, and I think any opinions are probably not specific to police, I think it would be just peoples general, societal opinion of things. I think ultimately, I don't think there is a strong underlying feeling amongst any of our officers, I think if anything it may vary from person to person, just based on their non-policing background, their own experiences (Participant 3).

Participants stated further that there was no need for their police services to create formal policy surrounding service provision towards undocumented/non-status community members because, it is not the responsibility of municipal police services to enforce immigration laws. As stated by a participant:

Within an organization that deals with community safety, our mandate is not to protect our border, that's the RCMP's or CBSA's responsibility (Participant 2, Chief of Police).

Participants explained that if a police officer came into the knowledge that someone was undocumented the procedure is to contact the Canadian Border Services Agency (CBSA) and once that is completed there is no further involvement of their municipal police service. As explained by a Senior Officer:

They just walk in, they come to us, or we come upon them, and they ask us for help. So this directive indicates our responsibilities, and it is basically about us making a lot of phone calls to Canada Border Services, and putting them in communication with them, and they [Canada Border Services] would totally deal with that (Participant 4).

They explained further that this procedure is not related to service provision:

So all it is, is what we do, so we need to call the CBSA and just follow these steps basically. It doesn't have anything to do though with service, all these directives are just indicating, no matter what the person's status is, if the person has a certain status, here is what you have to do (Participant 4, Senior Officer). 
Another participant described immigration as a secondary issue:

We have procedures in place, that speak to immigration, although that plays a secondary role in this, because if we deal with that type of matter, we immediately call Canadian Boarder Services and hand off the investigation. So we do have a procedure in place that speaks to that, but not specifically to sanctuary city policy. So any time we get anything to do with immigration, we hand it off (Participant 5, Superintendent).

While participants stated that it is not the responsibility of their police services' to enforce immigration law, an Inspector explained that the CBSA is a law enforcement partner and as such there are instances when they will work together:

For example enforcement of warrants or arrests, or requests, for example CBSA, working with them, we are expected of course through legislation to work with CBSA and execute immigration warrants (Participant 3).

Excluding the Toronto Police Service, no other police service in Ontario has a formal policy directing service towards undocumented/non-status community members, the current procedure is once it becomes known to a police office that someone is undocumented the CBSA is contacted and the municipal police service no longer has any involvement. Participants explained that this procedure is based on their duties as legislated by the Police Service Act:

The biggest challenge is that we have taken an oath to uphold the laws and it's all about the Police Services Act and I don't think there is any policy or procedure that we could put in place that would allow us to turn a blind eye or not fulfill our oath, in a nut shell (Participant 5, Superintendent).

Participants explained that while their police services' did not have a formal sanctuary city policy they had policies and directives surrounding the prevention of biased policing and on diversity and inclusion. For example:

We have standards that talk about biased policing, biased police profiling, it is continually being taught to them once or twice a year, about how to avoid the traps and the pitfalls of being involved or engaging in biased police. We pay strict attention to what our standards say about bias in our job. Including relating to hiring, we have a 
directive that says, 'You shall be proportionate to the makeup of the communities race and ethnicity' and we take that seriously (Participant 2, Chief of Police).

We have procedures in place for victims and witnesses and I honestly believe we have things in place that assist victims and witnesses especially in the diverse communities (Participant 5, Superintendent).

There is not a specific policy in regards to that. We provide service to all members of the community regardless of their status, their immigration status. So there would be a variety of policies that would be in existence, for example our Diversity policy (Participant 3, Inspector).

Participant statements represent a diversity of approaches and perspectives on the issue of sanctuary city policy in the context on municipal policing. There is not a singular voice on the issue of service provision and police service development of sanctuary city policy and/or the adherence to municipalities' designation as a sanctuary city.

\section{Challenges Creating Sanctuary City Policy in the Context of Policing}

The majority of police services raised the issue that while municipalities may have the authority under the Ontario Municipalities Act to vote on and declare a city a sanctuary city, they have no jurisdictional impact on police services. This represented the most commonly identified challenge to police services in the development of sanctuary city policy. For example, one participant explained:

They can declare it, but are we going to enforce it, how much time are we going to spend enforcing it. We may run across sanctuary issues from time to time, but trust me we are not creating a special task force to go out there and deal with the issue. If it's an issue for them, they try to make it an issue for us, and as I said, it is driven by their ability to enact a bylaw, that tells them under the Municipal Act that they can do this. It could pose problems if it gets down to actually effecting, or attempting to effect police operations because they have no jurisdiction there. It would border on obstructing justice, or causing someone to do something they would not normally do by way of a by-law, and again I think, you have head of councils telling you to do something, definitely that is counter to 
the Police Services Act. Even the Board Chair can't direct a police officer to do something (Participant 2, Chief of Police).

Another two participants explained further:

For policing the issue is that we are bound to respond to statute violations related to the criminal code, any other federal statute, along with any other statute at the provincial level, we don't have the luxury of being able to turn to a municipality and say, 'okay we are going to adopt your philosophies and your principles', because our practices are not dictated by the municipality, it is exclusively the realm of the province. The province decides what we will and will not do. As a result, the province has decided that we will enforce federal and provincial statutes, now there are some federal statutes that we assign to other policing agencies to deal with, such as immigration, and immigration takes care of that. There are also lots of different financial crimes that we hand over to the RCMP to investigate, so it's not that we will or won't do anything that the municipality asks for, they don't have the jurisdiction to tell us what to do (Participant 5, Superintendent).

It's important to be aware of that, municipalities, again, don't have any say or jurisdiction in terms of how police services are delivered as defined by the Police Services Act. It is actually spelled out quite clearly that municipalities cannot impact operations of the police, they cannot. So for example if a municipality said that 'we feel this is an issue and we would like the police service to actually do X,Y, \& Z, because we as a council have decided that this is a priority for us', that's prohibited. Not because the police say so, because the Police Services Act says so. Police Service Boards, municipalities, cannot give direction in terms of operations, that's what it would be described as, if they said, 'we would like you to do X,Y, \& Z, in terms of this enforcement or not', that's an operational issue, that is prohibited by legislation. I think it's important for that to be pointed out, and it's the same legislation that dictates what we do under certain circumstances. So if there was a change to legislation, then of course then we would follow it, because that's our service delivery model, and what we do, that's how it's impacted (Participant 1, Inspector).

The challenge participants identified represents a jurisdictional tension between municipalities and police services and was explained as the most significant barrier to overcome in the context of police service development of sanctuary city policy and/or the adherence to a municipalities designation as a sanctuary city. 
One participant raised the concern that surrounding the issue of sanctuary cities there is a

misrepresentation of information being presented to the public, they explained:

You have to be careful with what you read and who the source is, and the newspaper, and it's good to be clear, that it is also reasonable and appropriate that police services and the executive of police services and police services board would be mindful of the communities that they are in, and be mindful, similar to what I mentioned before, that policies are impacted by your jurisdiction. That is for assessment and evaluation, by the chief of a police service to be mindful of and take actions accordingly, but that's at the discretion of the chief and the executive, within the realm of the Police Services Act, that's operations, and that's the sole domain of police exclusively. Not open for interpretation, because legislation says so, not because the Chiefs say so, the PSA is very, very clear, municipalities do not impact operations of the police, they are governance, over sight, and review, exclusively, no exception. So regardless of what the media might print that makes for good reading, often times the information in there is not fulsome and not complete and accurate in terms of all the moving parts that would dictate yes or no (Participant 1, Inspector).

Participants further raised the concern that from their perspectives' the issue of service

provision towards undocumented/non-status community members has not been identified by

police services as an issue necessitating special focus:

I think it would be difficult because I think the police service here, as a whole would be sort of, "why do we need this", when we are already doing, we are already policing everyone and providing service to everyone. So, you know, why are we making another directive, there is a lot of directives that we have, so that would certainly be one where its, "okay here's another one", when we've never policed like that, so why do we need it (Participant 4, Senior Officer).

One participant explained how issues in policing become politicized:

You know we deal with issues that end up getting politicized, some as simple as, where do shopping carts go when they get taken off the lot of a grocery store. The city will enact a by-law that says 'You shall enforce the theft of shopping carts' and it specifically says 'the police and or by-law officers'. Yah, so they enact this, through a motion in council, saying here is our by-law dealing with runaway shopping carts, and I'll be damned if I am going to tell my guys to arrest anybody pushing a shopping cart home from Sobeys, but none the less, the city thinks they can do that and it is going to be acted 
upon. So it would be much the same thing with a sanctuary city declaration. It becomes fashionable to do those things sometimes (Participant 2, Chief of Police).

Participants recommended that given the jurisdictional tension that exists between municipalities and police services, the most effective solution would be a response and direction provided on police operation a the provincial of federal level:

I don't think it's something that a city, could or should be able to opt into or opt out of. It's a larger political decision at a higher level than a city. It's national, or very best it has to be provincial, so there has to be legislation covering it across the province, it would be even better, if it was federal because you would have a consistency of purpose then. Right now you have one city saying this is how we are going to do it, next door says that's how we're going to do it, it creates confusion (Participant 1, Chief of Police).

I think there needs to be some clarity at the Ministry level, to say okay, 'this is what you shall do', and those are the rules that we follow (Participant 6, Staff Sergeant).

It was further expressed by participants an understanding of the rational for the development of municipal police service sanctuary city policy, for example:

The last thing that you want is somebody that doesn't want to call 911 because they are afraid that they are going to have to leave the country. Certainly if that is an issue, that is something that we need to be aware of, and we do need to make policy if that is an issue, because that's the last thing that you want, something terrible happening to somebody just because of their fear of the unknown (Participant 6, Staff Sergeant).

\section{DISCUSSION}

\section{The 'Localization' of Borders and Police Service Practices}

The city is a crucial site of two conflicting process; claims to citizenship and the localization of border enforcement (Lebuhn, 2013). According to Lebuhn (2013), "this dual

process turns the urban realm into a conflictive site of negotiating, shaping and interconnecting local practices of border control and urban citizenship" (p. 37). The 'localization' of borders is understood as the involvement of municipal police services in the enforcement of immigration 
law. According to Armenta and Alvarez (2016), “although few law enforcement agencies directly enforce immigration law, many support the deportation regime by formally or informally cooperating with immigration enforcement agencies" (p. e12454). This reflects the main justification for sanctuary city policy, that because of fear of deportation undocumented/nonstatus community members cannot access police services (Ridgley, 2008). Participants explained it is not the role of municipal police services to enforce immigration law (Participant 2, 4, and 5). In the case where undocumented status becomes known, the procedure is to contact the CBSA. While it was identified that municipal police services are not responsible for or involved in the enforcement of immigration law, it was also identified by a participant that there are instances when police services will work in partnership with the CBSA. This same participant (Participant 4) also stated that regardless of immigration status, service is provided to all members of the community. It is open to interpretation whether the procedure of municipal police services to contact the CBSA can be understood as an act of enforcing immigration law. What is clear from these findings is that there is no singular voice from police services on the issue of sanctuary city policing. The seemingly contradictory statements represent the complexity of the development and implementation of sanctuary city policy in the context of municipal policing.

\section{Challenges of Sanctuary City Policy from the Perspective of Police Services}

Arguments in favour of sanctuary city policy including ensuring access to basic rights such as education, health care, and police services, all things that would improve the quality of life of undocumented/non-status community members. However, regarding the practical implementation of such policies, there are significant challenges from the perspective of police services that were identified throughout this study. The majority of police services raised the 
issue that while municipalities may have the power under the Ontario Municipalities Act to vote on and declare a city a sanctuary city, they have no jurisdictional impact on police services. A City Council may implement policies on access to services for undocumented/non-status community members, but this does not have an impact on police service operations. While discussion surrounding sanctuary cities is predominantly focused on the role and action of municipalities the study findings demonstrate the importance of including the role of the province as well. An example of the importance of the province is demonstrated by the actions of former Toronto Police Service Chief Blair in the decision to ignore recommendations by the Toronto Police Services Board to include a 'Don't Tell' component in a Non-Status Victims and Witness policy. Chief Blair justified the exclusion based on the position that it would require police officers to contravene their statutory duty to prevent crime as legislated by the Police Services Act (PSA). The PSA is provincial legislated. This demonstrates that the province and provincial legislation plays a key role to police service response in the development and/ or adherence to a municipality's designation as sanctuary city.

The question arose from participants that just because a municipality has raised this topic as an issue, does that mean it is an issue for police services. Given the jurisdictional tensions at play between Federal, Provincial, and municipal legislation, who can actually dictate what the response is to the issue? As one participant shared in an interview, if the changes came from the Provincial level, it is straight-forward for police services: they would simply comply and adjust procedures accordingly. The current police response is based on their interpretation of their obligations under the Police Services Act. There is very little precedent when it comes to this issue and there are concerns about liability. If an officer is in possession of the knowledge that someone is undocumented and they do not act on it because of 'don't tell' policy, if that results 
in something harmful towards community safety, is that officer or police service accountable? These are some of the concerns that were raised by police officers and regardless of one's position on the issue of sanctuary city policy, they are important to answer if there is to be a meaningful discussion on how police services should respond to the call for sanctuary city policy.

\section{CONCLUSION}

Sanctuary city policies aim to provide municipal and police services to all residents, regardless of immigration status. Such policies may further direct that municipal officials do not collect immigration/citizenship information for the purpose of determining service eligibility, or share personal information with federal authorities, unless specifically required to do so by provincial or federal authorities. A traditional understanding of citizenship is to view citizenship rights, responsibilities, and membership, as confined to the nation state (Purcell, 2003). From this perspective, citizenship is defined as a "legal status", which confers certain protections and rights within the nation-state. Contemporary debates surrounding the concept of citizenship demonstrate how societies are challenging the meaning of citizenship beyond its rigid legal category (Staeheli, 2003).

There is tension between the undocumented/non-status community and police services when police officers enforce immigration law, which additionally undermines the policecommunity partnership. Therefore, this study was conducted via interviews with police officers and an examination of the policies and practices of police services in Ontario as they relate to undocumented/non-status community members. The majority of police services raised the issue 
that while municipalities may have the power under the Ontario Municipalities Act to vote on and declare a city a sanctuary city, they have no jurisdictional impact on police services. There was recognition of the premise that sanctuary city is based on that if there is a fear of being deported, undocumented/non-status individuals will not feel safe accessing police services. As an Inspector stated, "ultimately, our goal is to keep people safe, and that is our focus, and I don't think that there is a police officer out there that would want someone to not report a crime, not to report it because they are afraid of getting deported, that would be terrible" (Participant 3). Many participants noted that the best solution to address the jurisdictional conflict between municipalities and police services is to have a provincial response that would legislate what actions police services must take. This demonstrates the centrality of the province and provincial legislation in discussion on the development of sanctuary cities and sanctuary city policy in the context of municipal policing. 
Appendix A

\section{TORONTO POLICE SERVICES BOARD \\ DRAFT}

\section{TPSB POL-XXX Victims and Witnesses Without Legal Status}

$\mathrm{X}$ New

Board Authority: Min. No. P34/06

Amended

Board Authority:

Reviewed

\section{RATIONALE}

To ensure that non-documented residents have equal access to policing services without the fear that contact with the police will lead to inquiries about their immigration status.

\section{BOARD POLICY}

It is the policy of the Toronto Police Services Board that the Chief of Police shall:

1. Develop procedures to ensure that victims and witnesses of crime shall not be asked their immigration status, unless there are bona fide reasons to do so.

2. Establish mechanisms to encourage victims and witnesses of crime to come forward without fear of exposing their status.

REPORTING:

LEGISLATIVE REFERENCE

\begin{tabular}{|c|c|c|}
\hline Act & Regulation & Section \\
\hline & & \\
\hline
\end{tabular}

SERVICE PROCEDURES: Refer to Service Procedures Index.

(Toronto Police Services Board, 2006, p. 20) 


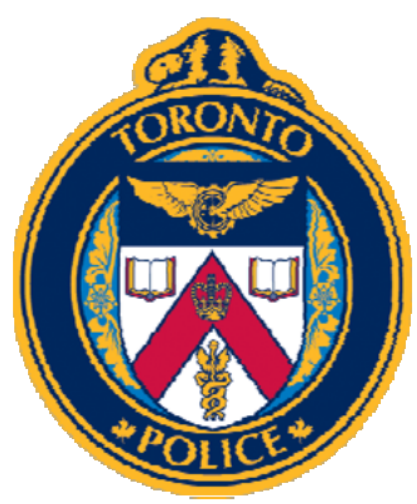

\section{VICTIMS AND WITNESSES WITHOUT LEGAL STATUS}

Police services should be available to all members of the community regardless of their immigration status.

Victims and witnesses of crime shall not be asked their immigration status, unless there are bona fide reasons to do so.

"bona fide reasons" means

- a victim or witness who may possibly require or may seek admission into the Provincial Witness Protection Program;

- a Crown Attorney is requesting information for disclosure purposes;

- the information is necessary to prove essential elements of an offence;

- investigations where the circumstances make it clear that it is essential to public or officer safety and security to ascertain the immigration status of a victim or witness. 


\section{Appendix C}

\section{Interview Guide}

1. What is your role and responsibilities within this Police Service?

2. Can you explain the structure of how operations and policies are disseminated through your Police Service?

3. Does your Police Service have formal policies surrounding service provision to undocumented/non-status community members?

4. Does your Police Service have informal policies surrounding service provision to undocumented/non-status community members?

5. What does the term sanctuary policy mean to you? 


\section{REFERENCE LIST}

Aleinikoff, A. (1991). A Case for Race- Consciousness. Columbia Law Review, 91(5), 10601125. Retrieved from http://www.jstor.org/stable/1122845

Armenta, A., \& Alvarez, I. (2016). Policing immigrants or policing immigration? understanding local law enforcement participation in immigration control. Sociology Compass, 11(2), e12453-n/a. doi:10.1111/soc4.12453

Balzacq, T., \& Guzzini, S. (2015). Introduction: 'What kid of theory - if any- is securitization?'. International Relations, 29(1), 97-102. doi: 10.1177/0047117814526606a

Basch, L., Glick Schiller, N., \& Szanton Blanc, C. (2003). Nations unbounded: transnational projects, postcolonial predicaments, and deterritorialized nation-states. London: Routledge.

Bauder, H. (2008). Immigration debate in Canada: How newspapers reported, 1996-2004. Journal of International Migration and Integration, 9(3), 289-310. doi:10.1007/s12134008-0062-z

Bauder, H. (2014). Why we should use the term 'Illegalized' refugee or immigrant: A commentary. International Journal of Refugee Law, 26(3), 327-332. doi: doi:10.1093/ijrl/eeu032

Bauder, H. (2016). Sanctuary cities: Policies and practices in international perspectives. International Migration, 12, 1-14. doi:10.1111/imig.12308

Bauder, H. (2017). Migration Borders Freedom. New York, NY: Routledge.

Burman, J. (2010). Suspects in the city: Browning the 'not-quite' Canadian citizen. Cultural Studies, 24(2), 200-213. doi: 10.1080/09502380903541647 
Buzan, B., \& Wæver, O. (2003). Regions and powers: The structure of international security. New York, US: Cambridge University Press.

Buzan, B., Wæver, O., and de Wilde, J. (1998). Security: A New Framework of Analysis. Colorado, US: Lynne Rienner Publishers, Inc.

City of Toronto, City Council. (2013, February 20). Undocumented Workers in Toronto. Ref no. CD18.5. Retrieved from http://app.toronto.ca/tmmis/viewAgendaItemHistory.do?item= 2013.CD18.5

City of Toronto, City Council. (2015, June 10). Toronto Police Service: Service Governance Pertaining to the Access to Police Services for Undocumented Torontonians. Retrieved from http://app.toronto.ca/tmmis/viewAgendaItemHistory.do?item=2015.CD4.2

City of Toronto, Social Development, Finance \& Administration. (2012, October 22). Undocumented Workers in Toronto. Ref no. AFS\# 15467. Retrieved from http://www.toronto.ca/legdocs/mmis/2013/cd/bgrd/backgroundfile-55291.pdf

City of Toronto, Social Development, Finance \& Administration. (2014, May 7). Access to City Services for Undocumented Torontonians. Ref no. 18943. Retrieved from https://www.toronto.ca/legdocs/mmis/2014/cd/bgrd/backgroundfile-69193.pdf

Cole, D. (2002). Enemy aliens. Stanford Law Review, 54(5), 953-1004. Retrieved from https://www-jstor-org.ezproxy.lib.ryerson.ca/stable/1229690?pqorigsite=summon\&seq=1\#page_scan_tab_contents

Coleman, M., and Kocher, A. (2011). Detention, deportation, devolution and immigrant incapacitation in the US, post 9/11. The Geographical Journal, 177(3), 228-237. 10.1111/j.1475-4959.2011.00424.x 
Deshman, A. (2009). To serve some and protect fewer: The Toronto Police Services' policy on non-status victims and witnesses of crime. Journal of Law and Social Policy, 22(8), 209235. Retrieved from h p://digitalcommons.osgoode.yorku.ca/jlsp/vol22/iss1/8

Ellis, B. D. (2015). The production of irregular migration in Canada. Canadian Ethnic Studies, 47(2), 93-112. Retrieved from http://ezproxy.lib.ryerson.ca/login?url=http://search.proquest.com/docview/1685997076? accountid=13631

Fanon, F. (1967). Black Skin White Mask, trans. Markmann, C. L. London: Grove Press Inc.

Gaucher, M. (2016). Monogamous Canadian citizenship, constructing foreignness and the limits of harm discourse. Canadian Journal of Political Science, 49(3), 519-538. doi: $10.1017 / \mathrm{S} 0008423916000810$

Goldring, L., Berinstein, C., \& Bernhard, K. J. (2009). Institutionalizing precarious migratory status in Canada. Citizenship Studies, 13(3), 239-265. Retrieved from https://yorkspace.library.yorku.ca/xmlui/handle/10315/10022

Guba, E. G., \& Lincoln, Y. S. (1988). Do Inquiry Paradigms Imply Inquiry Methodologies? In Qualitative Approaches to Evaluation in Education: The Silent Scientific Revolution (pp. 89-115). New York: Praeger Publishers.

Hegel, G. W. F. (1977). Phenomenology of Spirit, trans. Miller, A. V. London: Oxford University Press.

Holston, J., and Appadurai, A. (1996). Cities and citizenship. Public Culture: Bulletin of the Project for Transnational Cultural Studies, 8(2), 187-204. Retrieved from https://readdukeupress-edu.ezproxy.lib.ryerson.ca/public-culture/article/8/2/187-204/32194 
Hudson, G., Atak, I., Manocchi, M., Hannan, C.A. ( 2017, February). (No)Access T.O.: A Pilot Study on Sanctuary City Policy in Toronto, Canada. RCIS Working Paper. Retrieved from http://www.ryerson.ca/content/dam/rcis/documents/RCIS\%20Working\%20Paper\%2 02017_1GHudsonFinal\%20.pdf

Isin, E. (2008). The city as the site of the social. In E. F. Isin (Ed.), Recasting the Social in Citizenship (pp.261-280). Toronto, ON: University of Toronto Press.

Isin, E., Brodie, J., Juteau, D., and Stasiulis, D. (2008). Recasting the social in citizenship. In E. F. Isin (Ed.), Recasting the Social in Citizenship (pp.3-19). Toronto, ON: University of Toronto Press.

Jackson, P., Crang, P., \& Dwyer, C. (2004). Transnational Spaces. London: Routledge.

Lebuhn, H. (2013). Local border practices and urban citizenship in Europe: Exploring urban borderlands. City, 17(1), 37-51. 10.1080/13604813.2012.734072

Lennox, P. (2007). From golden straitjacket to Kevlar Vest: Canada's Transformation to a Security State. Canadian Journal of Political Science, 40(4), 1017-1038. doi: 10.1017/S0008423907071119

Magalhaes, L., Carrasco, C., \& Gastaldo, D. (2010). Undocumented migrants in Canada: A scope literature review on health, access to services, and working conditions. Journal of Immigrant and Minority Health, 12(1), 132-151. doi: 10.1007/s10903-009-9280-5

Meng, Y. (2017). Profiling minorities: Police stop and search practices in Toronto, Canada. Human Geographies, 11(1), 5-23. doi:10.5719/hgeo.2017.111.1

Messina, A. M. (2014). Securitizing immigration in the age of terror. World Politics, 66(3), 530559. doi: $10.1017 / \mathrm{S} 0043887114000148$ 
Muller, B. J. (2004). (dis)qualified bodies: Securitization, citizenship and 'identity management'. Citizenship Studies, 8(3), 279-294. doi:10.1080/1362102042000257005

Neuman, L., \& Robson, K. (2012). Quantitative and Qualitative Measurement. In Basics of Social Research: Qualitative and Quantitative Approaches (2 ${ }^{\text {nd }}$ Canadian ed.) (pp. 101118). Toronto: Pearson.

Nyers, P. (2010). No one is illegal between city and nation. Studies in Social Justice, 4(2), 127-1 43. Retrieved from http://journals2.scholarsportal.info.ezproxy.lib.ryerson.ca/details/19114788/v04i00 02/102_noiibcan.xml

Nyers, P., and Rygiel, K. (2012). Citizenship, migrant activism and the politics of movement. In P. Nyers and K. Rygiel (Eds.), Citizenship, Migrant Activism and the Politics of Movement (pp. 1-19). New York, NY: Routledge.

Ontario Association of Chiefs of Police. (2010). Ontario's Mobilization \& Engagement Model of Community Policing. Retrieved from http://www.oacp.on.ca/Userfiles/Files/NewAndEvents/CrimePreventionCampaign/COM MUNITY\%20POLICING\%20WHEEL-2.pdf

Police Services Act, RSO 1990, c P.15

Polkinghorne, D. (2007). Validity issues in narrative research. Qualitative Inquiry, 13 (4), 471780.

Pratt, A., \& Thompson, S. K. (2008). Chivalry, 'race' and discretion at the Canadian border. The British Journal of Criminology, 48(5), 620-640. doi:10.1093/bjc/azn048 
Pries, L. (2009). Transnationalisation and the challenge of differentiated concepts of space.

Tijdschrift Voor Economische En Sociale Geografie, 100(5), 587-597. doi:10.1111/j.1467-9663.2009.00566.x

Provine, D. M., \& Doty, R. L. (2011). The criminalization of immigrants as a racial project. Journal of Contemporary Criminal Justice, 27(3), 261-277. doi:10.1177/1043986211412559

Purcell, M. (2003). Citizenship and the right to the global city: Reimagining the capitalist world order. International Journal of Urban and Regional Research, 27(3), 564-590. doi:10.1111/1468-2427.00467

Ridgley, J. (2008). Cities of refuge: Immigration enforcement, police, and the insurgent genealogies of citizenship in U.S. sanctuary cities. Urban Geography, 29(1), 53-77. doi:10.2747/0272-3638.29.1.53

Rygiel, K.(2008). The securitized citizen. In E. F. Isin (Ed.), Recasting the Social in Citizenship (pp.211-238). Toronto, ON: University of Toronto Press.

Schulenberg, J. L. (2012). Systematic social observation of police decision-making: the process, logistics, and challenges in a Canadian context. Quality \& Quantity, 48(1), 297-315. doi: $\underline{10.1007 / s 11135-012-9769-1}$

Staeheli, L., A. (2003). Cities and citizenship. Urban Geography, 24(2), 97-102. doi: $10.2747 / 0272-3638.24 .2 .97$

Sweeney, M. A. (2014). Shadow immigration enforcement and its constitutional dangers. The Journal of Criminal Law and Criminology (1973-), 104(2), 227-282. 
The Immigration Legal Committee. (2008, May). Police Services: Safe Access for All Legal Arguments for a Complete "Don't Ask, Don't Tell" Policy. Retrieved from http://toronto.nooneisillegal.org/sites/default/files/Immigration\%20Legal\%20Committee \%20Report\%20Re\%20Toronto\%20Police\%20November\%202008.pdf

Toronto Police Service. (n.d). Victims and Witnesses Without Legal Status. Retrieved from http://www.torontopolice.on.ca/publications/files/victims_and_witnesses_wthout_legal_s tatus.pdf

Toronto Police Services Board. (2005, August 11). Minutes of the Toronto Police Services Board. Retrieved from http://www.tpsb.ca/component/jdownloads/send/18-2005/29405aug $11 \mathrm{pmm}$

Toronto Police Services Board. (2006, May 18). Minutes of the Toronto Police Services Board. Retrieved from http://www.tpsb.ca/component/jdownloads/send/19-2006/30006may18pmm

Toronto Police Services Board. (2008, November 20). Minutes of the Toronto Police Services Board. Retrieved from http://www.tpsb.ca/component/jdownloads/send/21-2008/338minutes-nov-20-public

Villegas, P. E. (2015). Fishing for precarious status migrants: Surveillant assemblages of migrant illegalization in Toronto, Canada. Journal of Law and Society, 42(2), 230-252. doi:10.1111/j.1467-6478.2015.00706.x

Watson, S. D. (2012). 'Framing' the Copenhagen School: Integrating the literature on threat construction. Millennium: Journal of International Studies, 40(2), 279-301. doi: 10.1177/0305829811425889

Whitelaw, B., \& Parent, R. B. (2010). Community-Based Strategic Policing in Canada (3 ${ }^{\text {rd }}$ ed.). Toronto, ON: Nelson Education Ltd 
Wortley, R. K. Measuring Police Attitudes Towards Discretion. Criminal Justice and Behavior, 10(5), 538-558. doi: 10.1177/0093854803254805 